Jurnal Care Vol .6, No.2,Tahun 2018

\title{
"Manusia Yang Berusaha, Tuhan Yang Menyembuhkan" : Persepsi Tentang Peran Tuhan Pada Penderita Diabetes Melitus Tipe 2
}

\author{
Nurul Hikmah ${ }^{1}$, Iman Permana ${ }^{2}$, Yanuar Primanda ${ }^{2}$ \\ ${ }^{1}$ Mahasiswa Magister, Program Studi Magister Keperawatan Fakultas Pasca \\ Sarjana Universitas Muhammadiyah Yogyakarta \\ ${ }^{2}$ Dosen,Program Studi Magister Keperawatan Fakultas Pasca Sarjana Universitas \\ Muhammadiyah Yogyakarta \\ e-mail: nersnurulhikmah@gmail.com
}

\begin{abstract}
Type 2 diabetes mellitus patients make an effort to prevent complication by implementing self care behavior. Individual perception on this effort is considered important to give optimal result. One factor that influences self care process is religious faith or believing in the role of God. This research aims at finding out the perception of Type 2 diabetes mellitus patients on the presence of God's role in their recovery process along with self care behavior. The research method used in this study was qualitative with fenomenology approach. There were 6 participants chosen using purposive sampling. The data was analyzed with Colaizay using content thematic technique. The result reveals one big theme that is people keep trying and God is the one who heals. This theme is supported by 2 sub-theme, they are attitude towards self care behavior and the belief that God is the ultimate decision maker for every events in our lives. The patrticipants believe that God has a big role in their recovery process, even so, they also believe that making the effort to take care of themselves is as important. This perception is stated by participants with different religious beliefs. It is concluded of this study have shown that participants have the same perception on the role of God which is believed to have the power to determine the end result of self care effort.
\end{abstract}

Keywords: God locus of control; self care behavior; Type 2 diabetes mellitus

\begin{abstract}
ABSTRAK
Penderita diabetes melitus tipe 2 melakukan upaya pencegahan komplikasi dengan cara menerapkan upaya self care behavior. persepsi individu tentang upaya ini dianggap penting agar memberikan hasil yang optimal. Satu hal yang mempengaruhi proses self care adalah keyakinan dalam beragama atau keyakinan
\end{abstract}


tentang peran Tuhan. Penelitian ini bertujuan untuk mengetahui persepsi penderita diabetes melitus tipe 2 tentang adanya peran Tuhan dalam kesembuhan disertai upaya self care behavior. Metode penelitian yang digunakan adalah metode kualitatif dengan pendekatan fenomenologi. Partisipan berjumlah enam orang dengan menggunakan teknik purposive sampling. Analisis data dengan Colaizzy menggunakan teknik tematik konten. Hasil penelitian menemukan satu tema besar yaitu "Manusia tetap berusaha, Tuhan yang menyembuhkan". Tema ini didukung dari 2 sub tema yaitu "perilaku ke arah self care behavior" dan "yakin Tuhan penentu setiap kejadian". Partisipan meyakini bahwa Tuhan memiliki peranan yang besar dalam proses kesembuhan, walaupun demikian mereka tetap menganggap upaya perawatan diri sama pentingnya. Persepsi ini diungkapkan dari partisipan dengan agama yang berbeda. Kesimpulan penelitian ini menunjukan bahwa partisipan memiliki persepsi yang sama tentang peran Tuhan yang diyakini menentukan hasil akhir dari upaya perawatan diri.

Kata kunci: diabetes melitus tipe 2;God locus of control; self care behavior

\section{PENDAHULUAN}

Berdasarkan data yang diperoleh dari International Diabetes Federation (IDF) pada tahun 2016 prevalensi DM berjumlah lebih dari 425 juta orang diseluruh dunia (IDF, 2017).Salah satu negara yang mengalami peningkatan prevalensi DM yaitu Indonesia yakni berjumlah 10,2 juta penderita (IDF, 2017). Daerah Istimewa Yogyakarta (DIY) merupakan provinsi dengan prevalensi tertinggi dibandingkan dengan provinsi di Indonesia dengan prosentase 2,6\% (Riset kesehatan dasar, 2013).

Tingginya prevalensi DM dikhawatirkan akan meningkatkan resiko penyakit penyerta sebagai akibat dari komplikasi penyakit ini.Komplikasiyang terjadi pada DM di Indonesia diantaranya adalah komplikasi neuropati 60\%, penyakit jantung koroner 20,5\%, ulkus diabetika $15 \%$, retinopati $10 \%$, dan nefropati 7,1\% (Satriawibawa dan Saraswati, 2011). Data ini 
menunjukan bahwa komplikasi ini meningkat seiring dengan peningkatan kejadian DM. Walaupun demikian, upaya pencegahan bisa dilakukan dengan cara melakukan penatalaksanaan DM melalui self care behavior secara optimal (Hasanat, 2015). Penelitian telah menunjukan bahwa self care behavior terbukti dapat menurunkan kadar gula darah (Putri dan Isfandiari, 2013).

Penderita DM menerapkan penatalaksanaannya melalui beberapa metode perawatan diri seperti pemilihan asupan makanan, aktivitas fisik, pengobatan yang tepat, perawatan kaki dan monitor gula darah secara mandiri (Toobert et al, 2000; Ayele et al, 2012; Sulistria, 2013). Penelitian menunjukkan bahwa ada hubungan self care behavior dengan jumlah komplikasi pada pasien DM tipe 2, bahwa semakin baik self care behavior maka semakin rendah angka kejadian komplikasi dan mampu meningkatkan kualitas hidup (Kiratnawati, 201 Shrivastava et al, 2013). Kepatuhan pengobatan terbukti positif mempengaruhi kontrol gula darah, kualitas hidup, pemeliharaan kesehatan biaya dan mampu mengurangi komplikasi kardiovaskuler (Song, 2012).

Hal ini menunjukan penderita DM tipe 2 yang melaksanakan self care behavior mengalami perubahan positif dalam kehidupannya. Walaupun demikian, kenyataannya bahwa banyak pasien DM mengalami kesulitan dalam menerapkan self care behavior, sehingga mengakibatkan glukosa darah yang tidak terkontrol (Novitasari, 2012). Penelitian Safitri (2013) tentang kepatuhan pasien DM dalam hal menjalani pengobatan, diet, mengontrol kadar glukosa darah, olahraga secara teratur dan menjaga kebersihan, menunjukan bahwa lebih dari $50 \%$ 
atau sekitar 48 responden dari 85 subjek penelitian terdapat termasuk dalam kategori kepatuhan rendah. Penelitian lain juga menunjukan bahwa berdasarkan beberapa survei tentang kepatuhan pasien terhadap pengobatan DM, antara lain ditemukan $75 \%$ tidak memakan makanan sebagaimana yang dianjurkan dan 75\% tidak makan secara teratur(Budiyani, 2010). Dengan demikian, kemampuan dalam mengontrol perilakunya sendiri sangat diperlukan oleh pasien DM untuk mencapai kepatuhan dalam self care behavior (Budiyani, 2010; Subiyanto, 2010).

Salah satu faktor yang mempengaruhi pasien DM dalam kepatuhan self carebehaviour adalah locus of control (Kadirvelu et al, 2012; Safitri, 2013).Locus of control adalah keyakinan individu bahwa ia memiliki kemampuan mengatur kehidupannya, atau justru orang lainlah yang mengatur kehidupannya (Dipayanti \& Chairani, 2012;
Adnyani, 2015).Keyakinan penderita DM tipe 2 tentang upaya self care behavior terkait dengan kesehatannya maupun pencegahan komplikasi hal ini disebut dengan bealth locus of control (HLOC) (Wallston et al, 2009). Dalam HLOC terdapat Pemahaman individu dan faktor perilaku yang dapat diperdalam kembali dengan cara mempelajari harapan individu terhadap peluang dan takdir diluar kontrol eksternal (Levenson, 1973). Berangkat dari pendapat ini, Wallston (1999) mengembangkan multidimentional health locus of control scale. Salah satu skala yang dikembangkan Wallston adalah God locus of control dimana hal ini dianggap sebagai salah satu faktor yang mempengaruhi upaya seseorang dalam self care behavior (Przybylski, 2010; Hjelm, 2013; Rydlewska, 2013;DiNatale, 2014; Adnyani, 2015; Aflakseir, 2015; Permana dan Harbiyan, 2015).

GLOC merupakan keyakinan terhadap peran Tuhan dalam 
menentukan peristiwa-peristiwa yang terjadi dalam kehidupan seseorang, yang mampu menghasilkan strategi koping yang positif dalam menghadapi stress terhahadap proses pemulihan pada orang-orang yang menderita penyakit kronis (Mamlin et al, 2001; Leaks, 2008; Utami, 2012; Zulkaida et al, 2012). Selain itu juga GLOC berhubungan dengan kepasrahan seseorang dalam menerima penyakit yang dideritanya (Wong \& Gorsuch, 2000; Livingstone, 2011). Menurut Pargament (2000 dalam Livingstone, 2011) kepasrahan adalah upaya maksimal yang dilakukan oleh seseorang untuk mendapatkan kesembuhan sampai akhirnya menyerahkan sepenuhnya kepada ketentuan Tuhan. GLOC Melalui kepasrahan ini akan menimbulkan jiwa yang tenang, sabar.

Sebagian besar masyarakat Indonesia sebagai negara yang terdiri dari berbagai macam latar belakang agama percaya akan adanya peran Tuhan. Begitu juga masyarakat Jawa di Yogyakarta bahwa secara budaya dan agama mereka percaya adanya peran Tuhan dalam setiap kehidupan manusia (Budiati, 2010), termasuk di dalamnya dalam hal upaya perawatan diri pada penderita DM tipe 2. Nilai budaya dan agama ini diistilahkan sebagai pasrah lan sumarah (kepasrahan), lila legawa ((Ikhlas), kodrat wiradat (usaha sebagai bentuk penerimaan takdir)dan narima ing pandum (kesadaran akan adanya perbedaan takdir pada setiap manusia). Istilah ini merupakan suatu nilai-nilai budaya Jawa sebagai bentuk kepasrahan, rela dan ikhlas dalam menghadapi penyakit DM yang dideritanya, walaupun demikian mereka tetap berupaya dalam menentukan nasib dan peruntungannya (Ch dan Sudarsono, 2008; Tumanggor, 2010). Nilai-nilai inilah yang mendukung nilai-nilai 
yang terkandung dalam prinsip GLOC.

\section{METODE PENELITIAN}

Desain penelitian ini menggunakan metode kualitatif dengan pendekatan fenomenologis, yaitu suatu prosedur penelitian yang bermaksud untuk memahami fenomena tentang apa yang dialami oleh subjek peneliti (Cresswell, 2014).Jenis pendekatan fenomenologi yang digunakan adalah dengan cara mengumpulkan informasi tentang keadaan-keadaan nyata sekarang yang sementara berlangsung bertujuan untuk mendeskripsikan apa-apa yang saat ini berlaku dalam menemukan ide baru (Van Manen, 2013; Nursalam, 2014). Partisipan dipilih dengan tehnik purposive samplingyang merupakan suatu metode penentuan sample dengan pertimbangan tertentu, partisipan dipilih berdasarkan kriteria dan tujuan penelitian

(Soegiyono,
2007).Partisipan yang dipilih dalam penelitian ini adalah pasien DM tipe 2 yang datang berobat di Klinik Firdaus UMY, bersuku Jawa.Jumlah partisipan dalam penelitian ini berjumlah 6 partrisipan. Pemilihan partisipan pada penelitian kualitatif dengan pendekatan fenomenologi pada umumnya terdiri dari tiga sampai dengan sepuluh partisipan (Creswell, 2014).

Pada penelitian ini menggunakan wawancara semiterstruktur, yaitu wawancara bersifat terbuka namun ada batasan tema dan memiliki alur pembicaraan, kecepatan wawancara dapat diprediksi, fleksibel tetapi tetap terkontrol, ada pedoman wawancara yang dijadikan patokan dalam alur, urutan dan penggunaan kata, dan tujuan wawancara adalah untuk memahami suatu fenomena (Soegiyono, 2007). Peneliti menggunakan analisa data yang 
digunakan Colazzy dengan menggunakan tematik konten.

\section{HASIL}

Tema besar dari penelitian ini adalah "Manusia tetap berusaha, Tuhan yang menyembuhkan", memiliki makna tentang adanya peran Tuhan yang besar dalam kesembuhan, walaupun demikian upaya meningkatkan kesehatan tetap dianggap penting. Tema ini didukung dari 2 sub tema yaitu "Perilaku ke arah self care behavior" dan "Tuhan penentu setiap kejadian”. 1). Perilaku ke arah self care behavior. Perilaku ke arah self care merupakan suatu upaya atau tindakan perawatan mandiri penderita diabetes melitus. Adanya upaya ini merupakan akibat dari interaksi antara individu dengan lingkungan sekitarnya. Interaksi ini bisa berupa dari pengalaman pribadi terkait selama menjalani DM tipe 2. Pengalaman ini didapatkan partisipan ketika pertama kali mengetahui DM tipe 2. Seperti yang diungkapkan partisipan P3 di bawah ini :

"perawat cek gula darab saya ternyata tinggi, kolesterol, asam urat semuaya tinggi e mbaaak, semenjake itu saya wes ra minum yang manismanis paling banter seminggu sekali klo kepengen buaaangeet minum yang pakei gula"

Pengalaman tersebut mengandung unsur pengetahuan bagi partisipan, dan apabila pengalaman tersebut menimbulkan suatu manfaat (reinforcement) maka dari situlah terbentuknya perilaku.

Self care behavior juga dipengaruhi oleh adanya social support, pada penelitian ini partisipan menyampaikan tentang bagaimana peran teman, tetangga maupun keluarga dalam menjalani penyakit ini. Social support ini dimanfaatkan oleh beberapa partisipan untuk mendapatkan 
informasi-informasi terkait tentang pengobatan medis, pengobatan traditional maupun terapi alternatif, seperti yang di ungkapkan partisipan P2 dibawah ini.

"... biasa saja mbaa kami apabila bertemu malaban ceritanya tidak masalah penyakit, tetapi masalah yang lain..paling -paling cerita tentang pengobatan di sana bagus di tempat ini bagus gituu azaa"

Selain faktor pengalaman selama menjalani penyakit dan adanya social support, perilaku juga terbentuk oleh praktek kesehatan yang dilakukan dalam bentuk self care behavior yang menjadi bagian dari aktivitas seharihari. Self care behavior di lakukan partisipan dengan berbagai macam cara dari pengobatan medis, alternatif dan herbal serta melibatkan ritual-ritual ibadah. Seperti ungkapan partisipan dibawah ini: "iyaaaa.....kalo obat iniiii saya minum setengah jam sebelum makan.."

Selain mengkonsumsi obat, partisipan juga berupaya dengan melakukan perubahan gaya hidup. perubahan gaya hidup ini meliputi pola makan, latihan dan aktifitas fisik.

"...saya sudab tidak makan nasi dan gula lagi, sekarang makan kentang ro gula tropicana slim.."

Berikut ungkapan terkait dengan aktifitas fisik :

"setiap hari bersib-bersih di halaman rumah, kalo gak cape bersepeda kadang seminggu sekali kadang seminggu 2 kali”

Partisipan lainnya mengungkapkan salah satu dari upaya self care behaviornya adalah menjaga kaki, berikut ungkapannya:

"menjaga kaki saya supaya jangan ada luka..." 
Self care behavior lainnya yang diungkapkan partisipan yaitu terapi alternatif komplementer. Berikut ungkapan partisipan terkait dengan penerapan terapi komplementer :

\section{"...3 kali seminggu menjalani akupressure" (P6)}

Selain terapi komplementer, sebagian besar partisipan masih menerapkan upaya penyembuhan dengan pengobatan tradisional yang disebut dengan jamu. Berikut ungkapan partisipan terkait dengan penggunaan Jamu :

"...yaa cuman Jamu-jamu Jawa ituu, seperti paitaaann badan saya enak kalo sudah minum jamu.."

Selanjutnya upaya self care behavior yang dilaksanakan partisipan yaitu dengan pendekatan terapi spiritual. Terapi spiritual ini merupakan pengobatan dengan cara melibatkan ibadah-ibadah dari agama yang di anut partisipan. Berdasarkan pengalaman partisipan yang beragama Islam mengungkapkan bahwa dengan berpuasa mampu membantu menurunkan kadar gula darah. Selain itu puasa, berdoa dan sholat juga bisa mendatangkan ketenangan. Begitu juga yang diungkapkan partisipan yang beragama kristen menyebutkan bahwa ibadah dalam bentuk senandung atau bernyanyi membuat jiwa menjadi lebih tenang dan damai. Berikut ungkapan partisipan terkait upaya perawatan diri dengan pendekatan terapi spiritual:

“.....selama menjalani puasa gula darah saya stabil..."

"adaa.. biasanya berdoa saya merasa menjadi lebih tenang, selain itu bersenandung juga selain membuat saya lebib tenang dan tidak gelisab tidak cemasan"

Beberapa kejadian tersebut mempengaruhi perilaku individu untuk self care behavior yang terdiri dari penglaman pribadi selama 
menjalani DM tipe 2, social support dan self care behavior.

Yakin Tuhan penentu setiap kejadian merupakan sikap yang datang dari perasaan yang mengetahui dan membenarkan penyebab suatu kejadian berasal dari Tuhan khususnya dalam penelitian ini terkait dengan penyakit yang dihadapi. Seperti yang diungkapkan partisipan P3 di bawah ini :

"itu adalah ikhtiar kita mbak..tapi jangan lupa tetap barus berdoa karena yang menyembubkan itu Allah..saya percaya itu mbaak...cuman berdoa saja tapi nda ada usahanya yoo percuma, begitu juga sebaliknya berusaha tapi nda berdoa yoo percuma juga.intinya berusaha sambil berdoa mbak"”

Ungkapan keyakinan ditandai dengan "yang menyembuhkan itu Allah" atau adanya suatu pembenaran dalam setiap usahanya bahwa berusaha dan berdoa adalah satu kesatuan yang tidak bisa dipisahkan ditambah dengan keyakinan bahwa yang yang menyembuhkan adalah Allah.

\section{PEMBAHASAN}

Manusia yang berusaha,Tuhan yang menyembuhkan, dapat bermakna bahwa segala apapun yang terjadi dalam kehidupan manusia itu adalah atas kehendak Tuhan termasuk sembuh atau tidaknya suatu penyakit, namun di sisi lain sebagai manusia diberikan kewajiban untuk terus berusaha dalam upaya meningkatkan kesehatan. Keadaan ini di dukung oleh hasil penelitian Polzer and Miles (2007), yang membahas bagaimana hubungan orang Afrika Amerika dengan Tuhannya terkait dengan upaya perawatan diri DM tipe 2. Mereka telah mengemukakan tiga tipe hubungan dengan Tuhan yaitu God in the Forefront, God in the Background, dan God is the Healer. God in the Forefront Tipe ini menggambarkan tentang 
keyakinan bahwa Tuhan memiliki peranan utama terhadap kondisi seseorang tanpa memperdulikan upaya yang telah dilakukan. Walaupun demikian, upaya perawatan diri tetap dilaksanakan. Yang kedua, God in the Background menggambarkan tentang keyakinan bahwa seseorang menganggap upaya perawatan diri adalah hal yang utama, namun Tuhan akan membantu mereka dalam hal menyediakan sumber daya seperti pengetahuan, serta bantuan dari praktisi kesehatan. Dan yang ketiga, God is the healer menggambarkan tentang keyakinan bahwa Tuhan akan memberikan solusi untuk masalah apapun jika orang tersebut memiliki iman yang kuat. Definisi God in the forefront dalam teori ini mendukung persepsi partisipan tentang peran tuhan dan upaya manusia. Seseorang dengan God in the forefront menunjukkan kecenderungan untuk lebih patuh dalam pelaksanaan praktik keagamaan dan lebih aktif dalam melakukan upaya perawatan diri (Permana dan Harbiyan, 2015; Stewart et al, 2013).

1. Perilaku kearah self care behavior. Hubungan timbal balik antara lingkungan dan individu dengan DM tipe 2 diharapkan mampu menghasilkan perilaku yang mengarah pada upaya meningkatkan kesehatan. Dalam penelitian ini faktor yang menentukan atau membentuk perilaku mengarah kepada self care behavior mencakup tiga hal yaitu bagaimana pengalaman pribadi individu tersebut maupun bagaimana dengan dukungan sosial dari keluarga maupun tetangga, serta bagaimana self care behavior itu sendiri dipraktekan dalam kehidupan seharihari. Perilaku ini didukung oleh beberapa pendapat tentang faktor yang berperan dalam menentukan atau terbentuknya perilaku dalam upaya meningkatkan kesehatan adalah adanya niat, adanya dukungan dari masyarakat sekitarnya (social 
support), terjangkaunya informasi, pengalaman, perilaku pemeliharaan kesehatan, dan sosial budaya (Notoatmojo, 2003; Yanti, 2009; Isworo, 2010; Muti'ah, 2010).

2. Yakin Tuhan penentu setiap kejadian

Meyakini bahwa Tuhan memiliki peran besar dalam kesembuhan merupakan bentuk keimanan seseorang. Keimanan mengacu pada pembenaran dengan segala keyakinan tanpa keraguan sedikitpun terhadap Tuhan (Jauhari, 2011). Melalui keimanan seseorang diberikan kemampuan untuk menerima keadaan dirinya. Penerimaan diri berlandaskan keimanan ini harus dimiliki individu dengan DM tipe 2. Sehingga, diharapkan mampu berperilaku perawatan diri yang positif. Penelitian dari Abdoli et al (2011) dan Watkins et al (2013) mengatakan bahwa keimanaan merupakan faktor yang sangat penting bagi individu dengan DM tipe 2 dalam melakukan perawatan diri mereka.Untuk pengembangan ilmu keperawatan diharapkan penelitian selanjutnya dikembangkan dengan desain penelitian mix method. Selain itu juga disarankan untuk penelitian selanjutnya untuk memperbanyak jumlah kota/kabupaten yang akan dijadikan sampel untuk meningkatkan generalisasi hasil penelitian karena banyaknya kota dan kabupaten yang termasuk dalam wilayah propinsi Daerah Istimewa Yogyakarta.

\section{KESIMPULAN}

Adanya persepsi tentang peran Tuhan dalam kesembuhan. Persepsi tersebut menempatkan Tuhan sebagai faktor utama dalam kesembuhan, walaupun demikian upaya perawatan diri tetap dianggap penting. Meskipun tidak terdapat perbedaan persepsi tentang keutamaan peran Tuhan dalam 
upaya self care behavior, namun untuk pelaksanaan asuhan keperawatan tetap mempertimbangkan latar belakang agama, sosial dan budaya untuk mengidentifikasi adanya sikap penerimaan yang mengacu kepada sikap pasrah tanpa berbuat apa-apa dengan dasar keyakinan nasib sudah ada yang menentukan yaitu Tuhan.

\section{REFERENSI}

Abdoli, S., Ashktorab, T., Ahmadi, F., Parvizy, S., \& Dunning, T. (2011). Religion, faith and the empowerment process: stories of Iranian people with diabetes. International journal of nursing practice, 17(3), 289-298

Adnyani, I. A. P. S., Widyanthari, D. M., \& Saputra, K. (2015). Hubungan health locus of control dengan kepatuhan penatalaksanaan diet DM tipe 2 di Paguyuban DM Puskesmas III Denpasar Utara. COPING NERS (Community of Publishing in Nursing), 3(3).
Ayele, K., Tesfa, B., Abebe, L., Tilahun, T., \& Girma, E. (2012). Self care behavior among patients with diabetes in Harari, Eastern Ethiopia: the health belief model perspective. PloS one, 7(4), e35515.

Budiati, A. C. (2010). Aktualisasi Diri Perempuan Dalam Sistem Budaya Jawa (Persepsi Perempuan terhadap Nilai-nilai Budaya Jawa dalam Mengaktualisasikan

Diri). Pamator Journal, 3(1), 51-59

Budiyani, K. (2010). Pelatihan manajemen diri untuk menurunkan kadar gula darah pada penderita diabetes melitus tipe II. . Psychoidea, 8(2).

Ch, M. N. A, \& Sudarsono (2008). Kearifan lingkungan dalam perspektif budaya Jawa. Yayasan Obor Indonesia.

Creswell, J.W. (2014). Research design, qualitative, quantitative and mixed methods approache (4 ed.). London: SAGE Publication Inc

Dipayanti, S., \& Chairani, L. (2012). Locus of Controldan Resiliensi pada Remaja yang Orang 
Tuanya Bercerai. Jurnal Psikologi, Vol. 8. No. 1, Juni 2012.

Jauhari, I. (2011). Kesehatan dalam Pandangan Hukum Islam. Kanun: Jurnal Ilmu Hukum, 13(3), 33-58.

Kiratnawati, D. (2012). Hubungan perilaku perawatan mandiri (self care inventory) dengan jumlah komplikasi pada penderita Diabetes melitus di Kelurahan Sumbersari wilayah kerja Puskesmas Dinoyo. Disertasi. Universitas Muhammadiyah Malang. Malang

Mamlin, N., Harris, K. R., \& Case, L. P. (2001). A methodological analysis of research on locus of control and learning disabilities rethinking a common assumption. The Journal of Special Education, 34(4), 214-225

Notoatmodjo S, 2003, Pengantar Pendidikan Kesehatan dan Ilmu Perilaku Kesehatan, Rineke Cipta Jakarta.

Novitasari, R. (2012). Diabetes melitus. Yogyakarta: Nuha Medika

Nursalam. (2014). Metodologi penelitian ilmu keperawatan. Pendekatan praktis edisi ke-3. Salemba Medika. Jakarta

Permana, I., \& Harbiyan, M. T. (2015). Javanese Muslim with Diabetes in Yogyakarta Managing The Daily Self-Care Activity. International Journal of Public Health Science (1JPHS), 4(4), 241-249.

Polzer, R. L., \& Miles, M. S. (2007). Spirituality in African Americans with diabetes: Selfmanagement through a relationship with God. Qualitative Health Research, 17(2), 176-188.

Przybylski, M. (2010). Health locus of control theory in diabetes: a worthwhile approach in managing diabetic foot ulcers. Journal of wound care, 19(6).

Putri, N. H. K., \& Isfandiari, M. A. (2013). Hubungan Empat Pilar Pengendalian DM Tipe 2 dengan Rerata Kadar Gula Darah. Jurnal Berkala Epidemiologi, 1(2), 234-243.

Rydlewska, A., Krzysztofik, J., Libergal, J., Rybak, A., Banasiak, 
W., Ponikowski, P., \& Jankowska, E. A. (2013). Health locus of control and the sense of self-efficacy in patients with systolic heart failure: a pilot study. Patient Prefer Adherence, 7, 337-343.

Safitri, I. N. (2013). Kepatuhan Penderita diabetes mellitus tipe II ditinjau dari locus of control. Jurnal Ilmiah Psikologi Terapan, 1(2), 273-290

Satriawibawa, I. W. E., \& Saraswati, M. R. (2011). Prevalensi Komplikasi Akut dan Kronis Pasien Diabetes Melitus Tipe 2 di Poliklinik Penyakit Dalam RSUP Sanglah Periode Januari 2011 - Mei 2012.

Shrivastava, S. R., Shrivastava, P. S., \& Ramasamy, J. (2013). Role of self-care in management of diabetes mellitus. Journal of Diabetes \& Metabolic Disorders, 12(1), 1

Soegiyono. (2007). Metode penelitian kuantitatif dan kualitatif. Bandung: Alfabeta

Song, Y., Song, H. J., Han, H. R., Park, S. Y., Nam, S., \& Kim, M. T. (2012). Unmet needs for social support and effects on diabetes self-care activities in Korean Americans with type 2 diabetes. The Diabetes

Educator, 38(1), 77-85

Sulistria, Y. M. (2013). Tingkat self care pasien rawat jalan diabetes melitus tipe 2 di Puskesma Kalirungkut

Surabaya. CALYPTRA: Jurnal Ilmiah Mahasiswa Universitas Surabaya, 2(2).

Toobert, D. J., Hampson, S. E., \& Glasgow, R. E. (2000). The summary of diabetes self-care activities measure: results from 7 studies and a revised scale. Diabetes care, 23(7), 943-950.

Utami, M. S. (2012). Religiusitas, koping religius, dan kesejahteraan subjektif. Jurnal Psikologi, 39(1), 46-66.161.

Van Manen, M. (2013). The call of pedagogy as the call of contact. Phenomenology \& Practice, 6(2), 834.

Wallston, K. A. (2005). The validity of the multidimensional health locus of control scales. Journal of bealth psychology, 10(5), 623-631.

Watkins, Y. J., Quinn, L. T., Ruggiero, L., Quinn, M. T., \& Choi, Y. K. (2013). Spiritual and religious beliefs and practices and social support's relationship to diabetes self-care activities in African Americans. The Diabetes Educator, 39(2), 231-239. 
Watkins, Y. J., Quinn, L. T., Ruggiero, L., Quinn, M. T., \& Choi, Y. K. (2013). Spiritual and religious beliefs and practices and social support's relationship to diabetes self-care activities in African Americans. The Diabetes Educator, 39(2), 231-239

Wulandari, O., \& Martini, S. (2013). Perbedaan Kejadian Komplikasi Penderita Diabetes Melitus Tipe 2 Menurut Gula Darah Acak. Jurnal Berkala Epidemiologi, I.
Yanti, S. (2009). Analisis bubungan kesadaran diri pasien dengan kejadian komplikasi diabetes mellitus dalam konteks asuban keperawatan di RSUD Dr. Adnan WD Payakumbub(Doctoral dissertation, Universitas Indonesia. Fakultas Ilmu Keperawatan.

Zulkaida, A. (2012). dkk. 2007. Pengaruh Locus of Control dan Efikasi Diri Terhadap Kematangan Karir Siswa Sekolah Menengah Atas (SMA). Proceeding Pesat, 2, B1B4. 